\title{
GLOSSOPTERIS OCCIDENTALIS WHITE EMENDED: GEOGRAPHIC AND BIOSTRATIGRAPHIC IMPLICATIONS
}

\author{
GRACIELA PEREIRATYBUSCH \& ROBERTO IANNUZZI \\ Depto. de Paleontologia e Estratigrafia, UFRGS, Av. Bento Gonçalves, 9500, 91509-900, Porto Alegre, RS, Brasil. \\ gracielatybusch@yahoo.com.br,roberto.iannuzzi@ufrgs.br
}

\begin{abstract}
Analysis of the type-material and new specimens from the Morro do Papaléo outcrop, in Rio Grande do Sul State, permitted the reevaluation of Glossopteris occidentalis White, 1908. The specific diagnosis is emended to include new features related to venation (midrib structure, angles of emergence and divergence of secondary veins, mesh shapes and vein density) and leaf shape. The emended diagnosis better discriminates this species from other members of the genus. The geographic distribution of this species, originally constrained to localities in southern Santa Catarina State, is now extended to Morro do Papaléo and Faxinal Mine localities in Rio Grande do Sul. Glossopteris occidentalis, considered previously to be restricted to the Rio Bonito Formation, has now been recorded in the uppermost part of the Itararé Group, extending its range from middle Sakmarian to early Artinskian.
\end{abstract}

Key words: Glossopteris occidentalis, Paraná Basin, Itararé Group, Rio Bonito Formation, Lower Permian, southern Brazil.

\begin{abstract}
RESUMO - A análise do material tipo e novos espécimes provenientes do afloramento Morro do Papaléo, no Rio Grande do Sul, possibilitou a reavaliação da espécie Glossopteris occidentalis White, 1908. A partir desta análise foi proposta uma emenda à diagnose original, onde foram incluídas novas características quanto à venação (venação mediana, ângulos de emergência e divergência da venação secundária, tipos de malha formada pela venação secundária e densidade de venação) e ao formato da folha. Esta nova diagnose permitiu uma comparação mais efetiva com as demais espécies já descritas para o gênero Glossopteris, o que confirmou G. occidentalis como um táxon válido. Além disso, foi possível ampliar a distribuição geográfica desta espécie, originalmente descrita para localidades ao sul do Estado de Santa Catarina, para os afloramentos Morro do Papaléo e Mina do Faxinal, ambos situados no Estado do Rio Grande do Sul. Em termos bioestratigráficos, G. occidentalis, um táxon até então restrito à Formação Rio Bonito, teve sua distribuição ampliada para o topo do Grupo Itararé, estabelecendo assim sua ocorrência para o Eopermiano (intervalo Sakmariano médio-Artinskiano precoce). As demais ocorrências fora da bacia do Paraná foram brevemente relatadas.
\end{abstract}

Palavras-chave: Glossopteris occidentalis, bacia do Paraná, Grupo Itararé, Formação Rio Bonito, Permiano Inferior, Brasil.

\section{INTRODUCTION}

Glossopterid leaves are the most abundant terrestrial macrofossils throughout the Permian of Gondwana. However, their limited range of characters has left them poorly resolved taxonomically. Even the generic characters have been reevaluated many times over the past 200 years by authors such as Brongniart (1828), Schimper (1869), Feistmantel (1876, 1881), Arber (1905), Pant \& Gupta (1968), Kovács-Endrödy (1976) and Chandra \& Surange (1979).

The chief problems for species delimitation within the genus are: (i) apparently great intraspecific variation in venation pattern, (ii) the relatively few morphological characters available in these simple leaves, and (iii) the scarcity of leaves with well-preserved cuticular characters or attached fructifications. Where only impressions are available, the identification of each glossopterid morphogenus is based upon lamina modifications (e.g. presence/absence of a sagittate base, secondary vein arrangement, and presence/absence of anastomoses). Leaf shape and size have generally been considered relevant only for morphospecies discrimination (Chandra \& Surange, 1979; Srivastava, 1991; Chandra \& Singh, 1992). Despite these difficulties, glossopterid leaves and fructifications have been commonly used to biostratigraphically subdivide the Permian successions of many Gondwanan basins (Chandra \& Surange, 1979).

Glossopteris occidentalis was the only species of the morphogenus Glossopteris to have been erected by D. White in his "Report on the Fossil Flora of the Coal Measures of Brazil", published in the Final Report of the "Comissão de Estudos das Minas de Carvão de Pedra do Brazil”, by I. C. White (White, 1908). This species has become known as one of the iconic fossils of the "Glossopteris Flora" in the Paraná Basin, and was considered endemic to Brazil.

However, in recent decades, the adequate comparison between D. White's species and other species of Glossopteris has become impracticable, since the diagnoses of many of the latter have been greatly extended to include a broad range of diagnostic characters not considered in the 
circumscription of G. occidentalis. The morphological parameters used by White for establishment of this species are generally considered insufficient, nowadays, for clear recognition of the species.

Recently, one of the authors (RI) re-examined the type material of G. occidentalis. Additionally, new specimens attributable to this species have been collected at the Morro do Papaléo outcrop, southern Brazil, in recent years. Therefore, the main goal of this study is to re-evaluate the diagnostic characters of Glossopteris occidentalis White, 1908 based on the type material and new specimens housed in the collection at UFRGS (Federal University of Rio Grande do Sul).

\section{GEOLOGY}

The type material of G. occidentalis was collected during the expeditions mentioned in the Final Report of I. C. White (White, 1908), to the Rio do Rastro Road (SC 438), near the city of Lauro Müller, in the State of Santa Catarina, southern Brazil. The specimens correspond to the Lot 3923 of White, which is equivalent to Horizon II (2) of Mendes (1952) and Rigby (1972). According to Mendes (1952), Horizon II is located stratigraphically above the "Bonito Coal" layer and bellow the "Irapuá Coal" layer, in the region of Lauro Müller. These coal layers are part of the Siderópolis Member, top of the Rio Bonito Formation in the coal basin of Santa Catarina State, according to Bortoluzzi et al. (1978).

The fossiliferous layer consist of yellowish-gray siltstones with weak lamination bearing indeterminate lycopsid leaves, Glossopteris and Cordaites (= Noeggerathiopsis) leaves, Paracalamites-type stems and Sphenopteris-type fern fronds, according to White (1908) and Rigby (1972).
In terms of depositional paleoenvironments, Bortoluzzi et al. (1978) indicated that the Rio Bonito Formation in this area accumulated in a low-gradient fluvial complex associated with swampy lagoons on a coastal plain. Krebs (2004) interpreted the interrelated facies identified in the Siderópolis Member to represent deposition within a lagoonal and deltaic system, under fluvial and wave influence. In this context, the fossiliferous layers are considered to represent fluvial floodplain deposits.

The new material comes from the Morro do Papaléo outcrop representing an abandoned kaolin mine located in the town of Mariana Pimentel, about $100 \mathrm{~km}$ southwest of Porto Alegre city (Figure 1). Samples were collected in stratigraphic context with reference to the profile measured by Iannuzzi et al. (2003a,b, 2006) representing the upper portion of the outcrop (Figure 2). Beds N4, N7 and N8 host Glossopteris occidentalis. Bed N4 represents the top of the Itararé Group in the section according to Iannuzzi et al. (2003a,b, 2006) and is composed of finely laminated, light gray siltstones bearing leafy axes of Phyllotheca and Stephanophyllites, leaves of Glossopteris, Gangamopteris, Cheirophyllum, ?Dicranophyllum, Kawizophyllum and Cordaites, and seeds of the Samaropsis and Cordaicarpus (Figure 2). Beds N7 and N8, located at the top of the exposed section at Morro do Papaléo belong to the Rio Bonito Formation, Guatá Group (Figure 2), and are composed of lensshaped bodies of coarse, conglomeratic sandstone, intercalated with fine whitish gray siltstones, as described by Iannuzzi et al. (2003a,b, 2006). Most of the material used in this study, together with impressions of diverse stems, fronds, leaves and seeds (Brasilodendron, Asterotheca, Neomariopteris, Pecopteris, Sphenopteris, Glossopteris, Gangamopteris, Arberia, Kawizophyllum, Cordaites, Ginkgophytopsis, Samaropsis and Cordaicarpus) derive

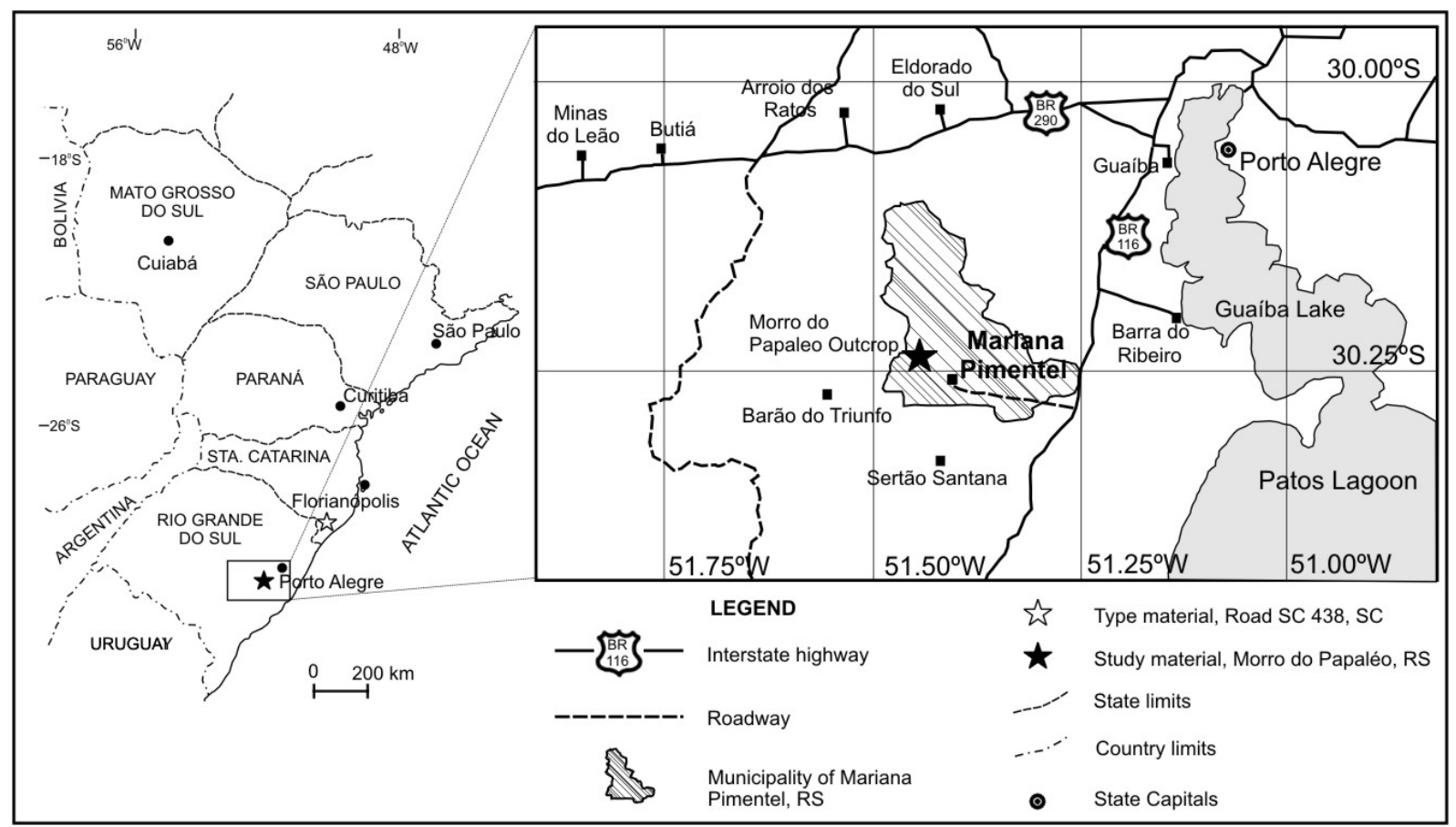

Figure 1. Map showing the Morro do Papaléo outcrop, town of Mariana Pimentel, Rio Grande do Sul State (black star). Note also the approximate location of the type material, Road SC 438, near town of Lauro Müller, Santa Catarina State (white star) (modified from lannuzzi et al., 2006). 


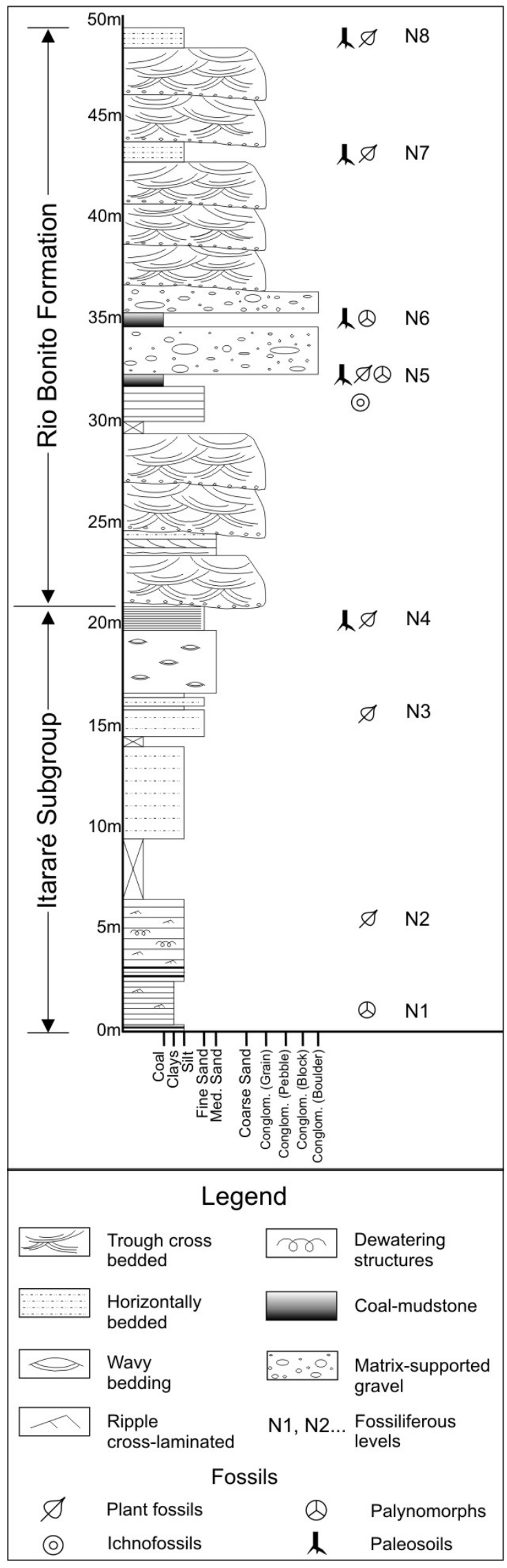

Figure 2. Stratigraphic section of the Morro do Papaléo outcrop showing the plant-bearing levels (N1, N2, etc.) as described in the text (modified from lannuzzi et al., 2006). from these siltstones. According to Iannuzzi et al. (2003a,b, fig. 1), the basal beds (N1 to N4), correspond to lagoonal or lacustrine deposits (Itararé Group), whereas beds N7 and N8 represent typical floodplain deposits (Rio Bonito Formation, Guatá Group).

\section{MATERIAL AND METHODS}

Four specimens constituting the type material (syntypes) of Glossopteris occidentalis White, 1908 in the National Museum of Natural History (Smithsonian Institution), prefixed USNM and 32 additional specimens collected from the Morro do Papaléo outcrop were analyzed. The latter are housed in the Paleontology Museum (PM) of the Department of Paleontology and Stratigraphy (DPE) of the Geosciences Institute (IGeo) of the Federal University at Rio Grande do Sul (UFRGS), cataloged under the code prefix $\mathrm{MP}-\mathrm{Pb}$.

The studied specimens are impressions, except for one syntype (USNM 31944), which is a compression. Thus, the material was studied using standard methodologies for leaf adpressions (observations and measurements were made with a stereomicroscope and caliper; the material was illustrated with the aid of digital photography and camera-lucida line drawings).

Leaf morphographic characteristics, such as the shape of the lamina and the types of leaf apices and bases, were defined in accordance with the scheme adopted by Chandra \& Surange (1979) adapted from Dilcher (1974); the characteristics of venation density, emergent and divergent angles of secondary venation, and the maximum width of the midrib venation follow the criteria of Rohn et al. (1984). Estimates of total leaf size for incomplete specimens derive from the scheme of Ash et al. (1999) modified of Webb (1959), in which seven classes of leaf size are defined according to the area of the lamina, namely: leptophyll, nanophyll, microphyll, notophyll, mesophyll, macrophyll and megaphyll. Terminology for vein anastomoses is that of Tybusch \& Iannuzzi (2008) as showed in Figure 3: (i) oblique crossconnections (veins originating at acute angles from a fork of the secondary veins; (ii) tranverse cross-connections (veins originating transversely from the dominant secondary veins, i.e., those sub-parallel to the midrib that connect neighboring secondaries); (iii) X-type cross-connections (veins originating from the convergence or crossing of neighboring secondary veins).

The supra-generic classification used herein is that of Stewart \& Rothwell (1993).

\section{SYSTEMATIC PALEONTOLOGY}

Division TRACHEOPHYTA
Class GYMNOSPERMOPSIDA
Order GLOSSOPTERIDALES
Genus Glossopteris Brongniart, 1828

Type species. Glossopteris browniana Brongniart, 1828.

Glossopteris occidentalis White, 1908 emend. (Figures 4-6)

1941 Glossopteris cf. G. ampla (auct. non.) Dana. Read, p. 7679, pl. 4 , fig. 5 .

1948 Taeniopteris sp. (auct. non.) Dolianiti, p. 17, pl. 6, fig. 1. 


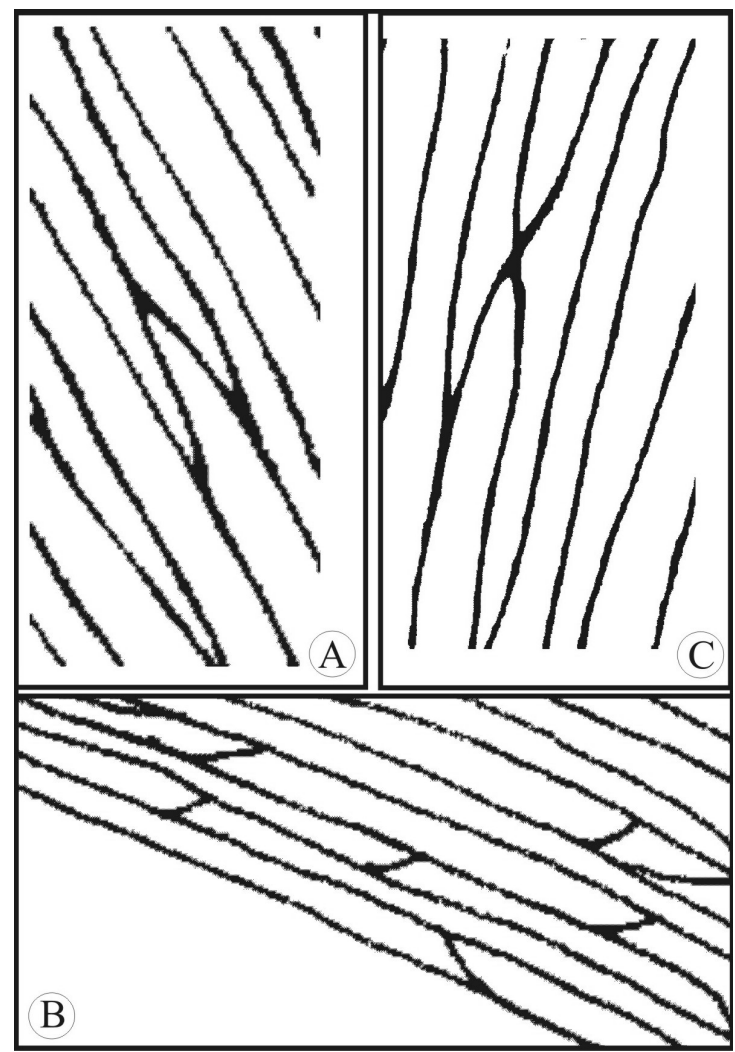

Figure 3. Three categories of anastomoses present in glossopterid leaves as defined by Tybusch \& lannuzzi (2008). A, oblique crossconnection; B, transverse cross-connection; C, X-type crossconnection (from Tybusch \& lannuzzi, 2008).

1953a Glossopteris stricta (auct. non.) Bunbury. Dolianiti, p. 2-4, pls. 1-2.

1953b Taeniopteris feddeni (auct. non.) Feistmantel. Dolianiti, p. 2-3, pls. 1-2.

Syntypes. USNM 31944, 31945, 31946 and 31947.

Additional material. MP-Pb 3570, 3650, 3696A, 3696B, 3711, 3712, 3713A, 3713B, 3716, 3717A, 3717B, 3718,3719, 3720,3721, $3722,3725,3726,3727,3728 \mathrm{abA}, 3728 \mathrm{abB}, 3728 \mathrm{aD}, 3728 \mathrm{aE}$, 3751, 3940, 3981, 3982, 3983A, 3983C, 3984A, 3985A, 3985B.

Type locality. Rio do Rastro Road (SC 438), near Lauro Müller, Santa Catarina State, southern Brazil.

Locality of additional material. Morro do Papaléo outcrop, in the town of Mariana Pimentel, Rio Grande do Sul State, southernmost Brazil.

Type horizon. Lot 3923 of White, equivalent to Horizonte II (2) of Mendes (1952) and Rigby (1972).

Stratigraphic position of additional material. Fossiliferous levels N4 (at the top of the Itarare Group) and N7 and N8 (Rio Bonito Formation), according to Iannuzzi et al. (2003a,b, 2006). Age. Early Permian (middle Sakmarian-early Artinskian).

Emended diagnosis. Oblanceolate to nearly oblanceolate leaf, margin entire with acute apex, in some cases rounded, base tapering acute, gradually contracting into a broad and winged petiole. Midrib broad, composed of multiple well-defined, thick, parallel veins that gradually decrease in width towards the apex and are locally interconnected by oblique veins. Secondary veins emerge from the midrib at angles of $15^{\circ}-39^{\circ}$ and bend sharply, then follow a straight and parallel course at nearly right angles to the midrib to the margin, immediately before which they arch gently distally, reaching the margin at angles of $60^{\circ}-79^{\circ}$. Venation density uniform along the leaf: 36-55 veins per $\mathrm{cm}$ in both middle and distal portions of the lamina. Secondary venation anastomosing, incorporating oblong-polygonal and short meshes near the midrib and by linear-oblong, trapezoid to polygonal meshes in the middledistal portion of the lamina; mesh density decreases towards the margin. Transverse-type cross-connecting veins present throughout the lamina.

Description of type material. See White (1908, p. 510-517) and Figure 4 herein.

Description of additional material. The additional specimens from Rio Grande do Sul are complete to variably fragmented impressions that all show excellent preservation of venation. The leaves have entire margins and vary from notophyll to macrophyll size; they may reach more than $40.9 \mathrm{~cm}$ long (e.g. $\mathrm{MP}-\mathrm{Pb}$ 3650: Figure 5B); widths are $6.2-11.2 \mathrm{~cm}$ in the more complete specimens, but may exceed $12.7 \mathrm{~cm}$ in some fragmentary specimens. The lamina varies from oblanceolate to narrowly oblanceolate (Figures 5B-D), but may include some specimens with a tendency towards oblong shape (MP$\mathrm{Pb} 3984 \mathrm{~A}$, Figure 5A) where more parallel margins are evident. Most specimens have tears in the lamina along the secondary veins. The apices are acute, though rounded in some cases (Figures 5B-E); the bases contract acutely into a broad and winged stalk or petiole (Figure 5D). The midrib is well defined, $1.0-1.4 \mathrm{~cm}$ wide in the proximal portions, but only $0.3-0.9$ wide in the middle parts. The midrib is formed by a bundle of around 19 to 20 thick parallel veins in the proximal portion, 11-18 veins, in the middle portion, reducing to about 8-4 veins in the distal region; the midrib persists to the apex. The midrib veins are locally interconnected by oblique cross-veins. The secondary venation is very clear, especially in specimen MP$\mathrm{Pb} 3570$ (Figure 6), due to the contrast produced by a thin coating of iron oxide on some specimens. The secondary veins derive from the midrib venation at $15^{\circ}-39^{\circ}$, and immediately arch sharply then pass straight and parallel, at almost right-angles to the midrib, towards the leaf margin forming a taeniopteroid pattern; close to the margin, the secondary veins curve slightly towards the apex, reaching the margin at $60^{\circ}-79^{\circ}$ (Figure 6). Venation density is roughly uniform throughout the lamina in the range: $36-46$ veins per $\mathrm{cm}$, although secondary vein density increases slightly from the midrib to the margin (Figure 6). Very narrow, elongate areolae occur between the secondary veins across most of the lamina except near the midrib where they are oblongtrapezoid/polygonal and slightly wider and shorter. Transverse-type cross-connections are predominant between the main secondary veins (Figure 6).

Discussion. There are strong similarities between the type material and the additional specimens from Rio Grande do Sul, although a few subtle differences are evident. Whereas the Rio Grande do Sul leaves vary from oblanceolate to narrowly oblanceolate (Figure 5), the syntype USNM 31944 (Figure 4B) has more parallel lateral margins suggesting a narrowly oblong lamina. Only specimens MP-Pb 3984 (Figure 5A) and MP-Pb 3985A approach this shape. White (1908) did not include gross shape characters in his diagnosis of $G$. occidentalis, since his material was limited and very fragmented. The apparent oblong shape of USNM 31944 (Figure 4B), is probably a taphonomic artifact since the left margin of the mid-lamina is slightly folded over itself. 
Another difference observed between the material analyzed and the type material was the venation density. While White's syntypes have venation densities of 48-55 veins per centimeter whereas that in the Rio Grande do Sul specimens ranges from 36-46 veins per centimeter. Material assigned by Bernardes-de-Oliveira $(1969,1977)$ to Glossopteris cf. G. occidentalis also has less dense venation $(35-42$ veins $/ \mathrm{cm})$. The latter specimens are from the Bainha outcrop, situated in the city of Criciúma, Santa Catarina State, southern Brazil, and also belong to the Siderópolis Member of Rio Bonito Formation. Thus, this material is located both geographically and stratigraphically close to the source of White's material. The high venation densities evident in the four syntypes studied by White may represent extreme values for the general population of this species (now represented by over 90 specimens).

Towing to these extended ranges of intraspecific variation, the original diagnosis has been emended. Additionally, the new material provides new and more detailed characters that allow more complete circumscription of the species and comparison with others.

Many specimens of G. occidentalis are characterized by deep and frequent lacerations across the lamina parallel to venation (White, 1908; Dolianiti, 1948, 1953a,b; Bernardes-
de-Oliveira, 1969, 1977; present study Figures 4A-B and 5AB). This feature suggests that the lamina was thin, but tearing was probably also facilitated by the strongly taeniopteroid arrangement of the secondary venation and weak crossconnections between the veins.

Few other species from Gondwana are similar to the Brazilian $G$. occidentalis. The venation pattern in $G$. occidentalis is broadly similar to Glossopteris gigas Pant \& Singh (in Chandra \& Surange, 1979; Chandra \& Singh, 1992), G. communis Feistmantel, G. damudica Feistmantel, G. indica Schimper (cf. Kovács-Endrödy, 1976; Chandra \& Surange, 1979; Chandra \& Singh, 1992) and G. plumata McLoughlin (in McLoughlin, 1993), with respect to the high density of veins and areolae shapes. Glossopteris taeniopteroides Feistmantel (in Maheshwari, 1965; Kovács-Endrödy, 1976), G. waginanus Rigby (in Rigby et al., 1988) and G. ampla Dana (in Archangelsky, 1958; Rigby, 1966; Kovács-Endrödy, 1976) are alike in the oblong, trapezoidal to polygonal meshes abutting the midrib transitioning to very narrow and elongated meshes in the middle and distal portions of lamina. However, G. occidentalis, as redefined here, is distinguished from G. communis, G. gigas and G. plumata in (i) having more uniform meshes across the leaf lamina (with meshes just a little wider close to the midrib), (ii) having less acute secondary
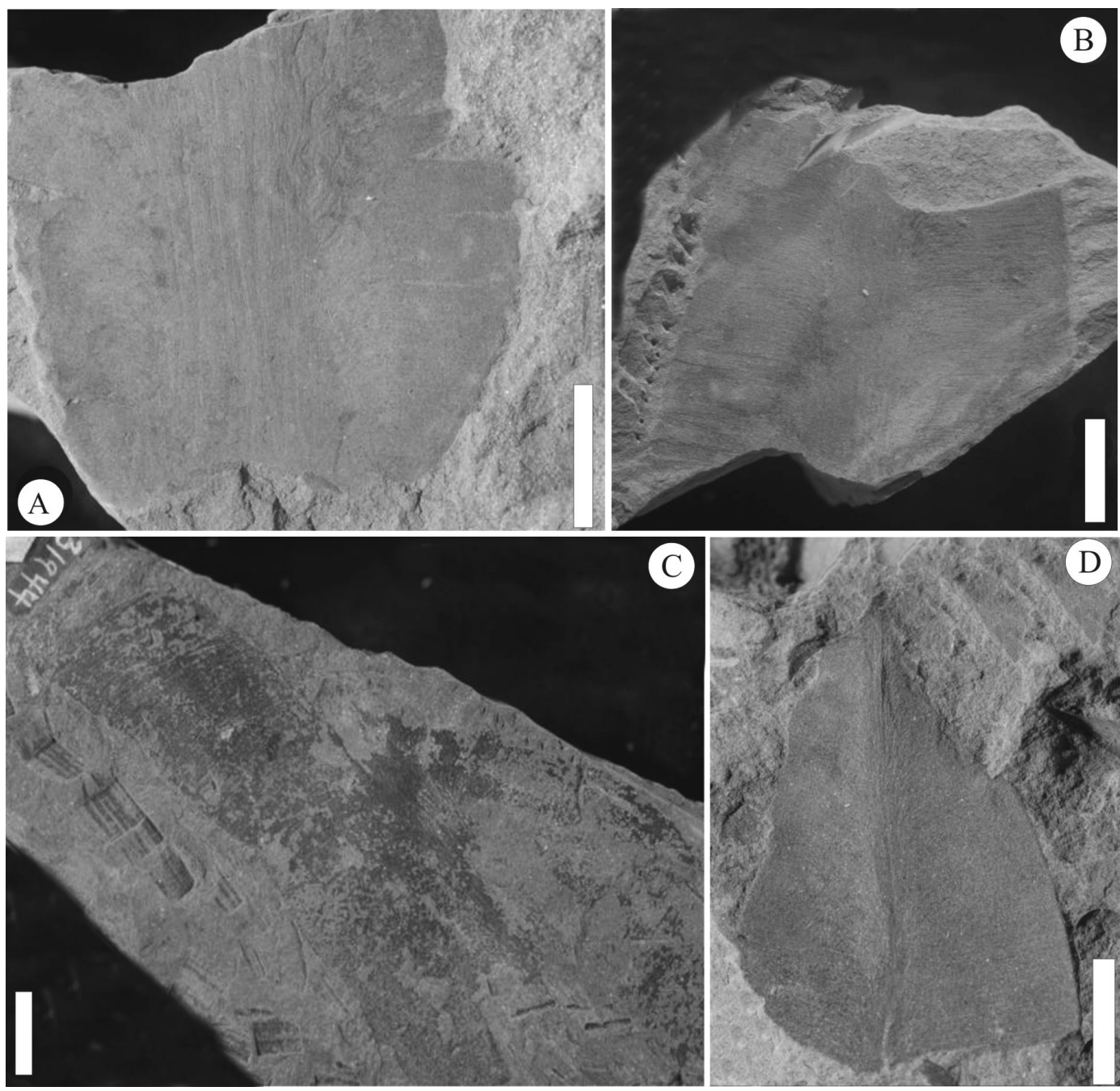

Figure 4. Glossopteris occidentalis (White) emended. A, syntype USNM 31945, showing the leaf base; B, syntype USNM 31944 , median region of leaf; C, syntype USNM 31946, apical region of leaf; D, syntype USNM 31947, fragment showing leaf apex. Scale bars $=1 \mathrm{~cm}$. 
veins emerging from the midrib that are joined by predominantly transverse-type cross-connections, and (iii) presenting the oblanceolate shape of the lamina, except in the case of G. plumata which shows also a oblanceolateshaped leaf. It differs from $G$. damudica in being larger with oblanceolate to narrowly oblanceolate shape, entire margin, acutely rounded apex, gradually contracted acute base and, less obtuse secondary veins. Glossopteris indica shares with G. occidentalis an oblanceolate shape (specimens with length/width ratio of 4:1), acute apex and the presence of oblique cross-connections amongst the secondary venation. However, G. occidentalis differs in having leaves with greater dimensions, bases truncate and acute bases that gradually contract towards the petiole, and secondary veins that emerge at less acute angles. Finally, G. occidentalis is also distinguished from G. taeniopteroides, G. waginanus and $G$. ampla in having a persistent and very broad midrib, higher venation density and oblanceolate to narrowly oblanceolate shape.

Glossopteris occidentalis is, thus, considered a legitimate taxon and readily distinguished from other species on the basis of characters outlined in the emended diagnosis.

Emendation is based on re-analysis of the syntypes and morphological characters preserved in 32 specimens in the paleobotanical collection of the Museum of Paleontology at DPE-IGeo-UFRGS, recovered from the Morro do Papaléo outcrop. The Rio Grande do Sul specimens provided key characters of the midrib and secondary venation not available in the syntypes, and this has allowed more precise comparison with other Glossopteris morphospecies.

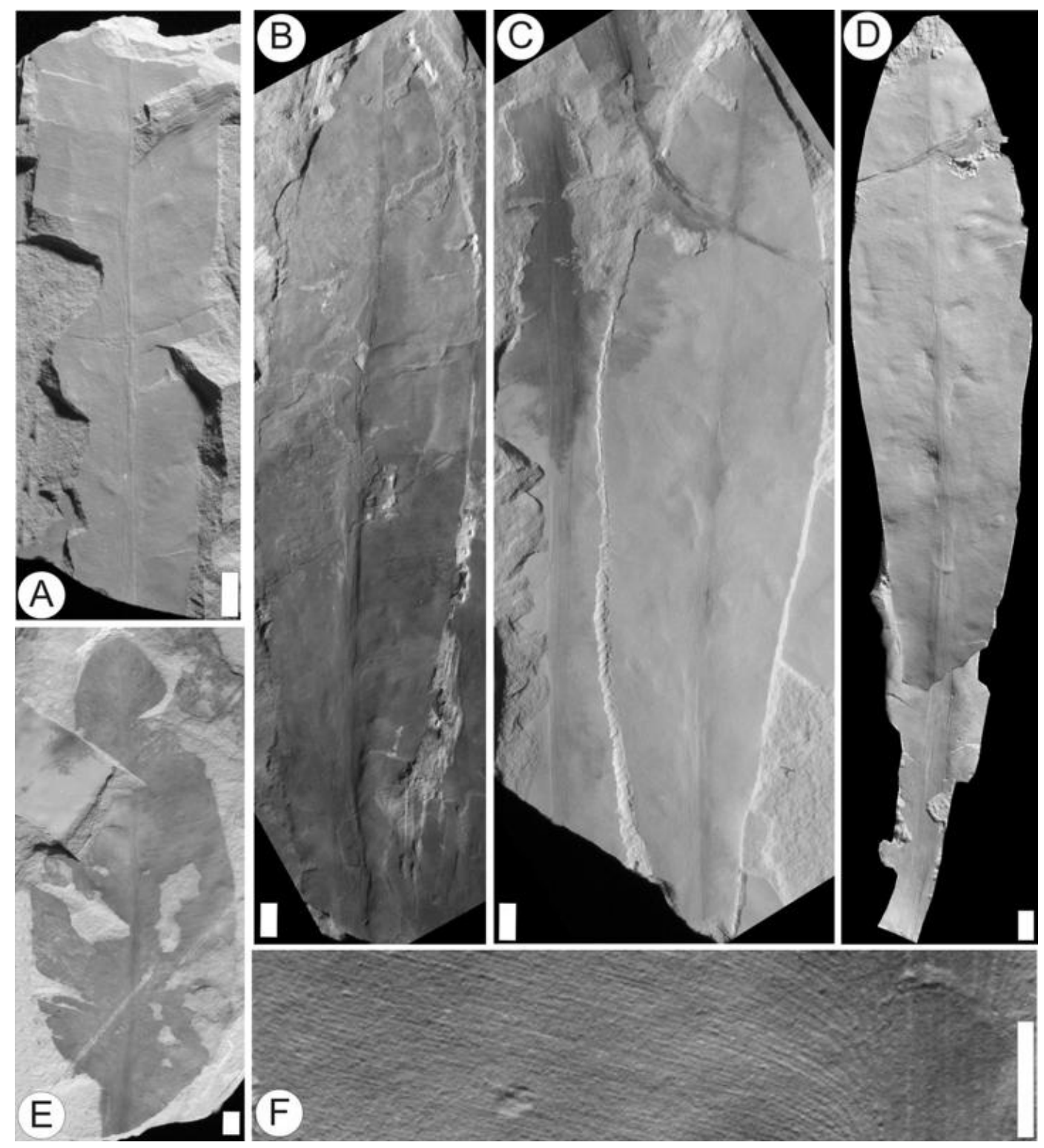

Figure 5. Glossopteris occidentalis (White) emended. A, specimen MP-Pb 3984A, leaf fragment with parallel margins, suggesting an oblong lamina; B, specimen MP-Pb 3650, almost complete narrow oblanceolate leaf with acute apex; C, specimen MP-Pb 3728AE, almost complete narrow oblanceolate leaf with acute apex, tapering gently to an acute base; $\mathbf{D}$, reconstruction of the leaf form from specimens MP-Pb 3728AE; E, specimen MP-Pb 3983A, apical and median region of oblanceolate leaf; F, specimen MP-Pb 3570 , details of the venation. Scale bars $=1 \mathrm{~cm}$ with exception of $\mathrm{F}(0.5 \mathrm{~cm})$. 


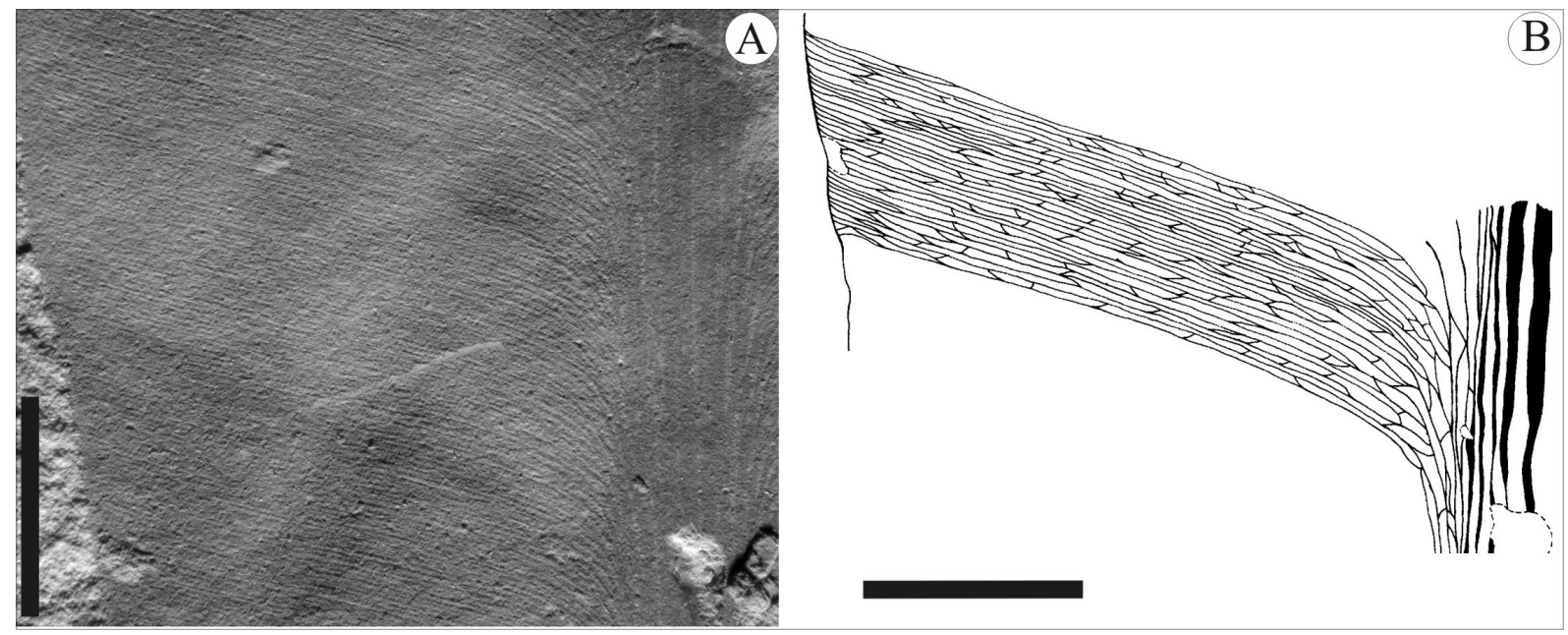

Figure 6. Glossopteris occidentalis (White) emended, specimen MP-Pb 3570. A, photo showing details of the venation; B, drawing showing the venation pattern. Scale bars $=1 \mathrm{~cm}$.

\section{DISTRIBUTION OF THE SPECIES}

Originally described by White (1908) from a site near Lauro Müller, southern Santa Catarina State, Brazil, the species is now also recognized from Bainha outcrop, city of Criciúma, Santa Catarina (Dolianiti, 1948, 1953; Bernardes-de-Oliveira, 1969, 1977) and Morro do Papaléo outcrop, Rio Grande do Sul (this study). Guerra-Sommer \& Cazzulo-Klepzig (1993) had earlier suggested the occurrence of G. occidentalis in Rio Grande do Sul (Mina do Faxinal locality, Rio Bonito Formation). However, the authors did not described or illustrate the material.

Besides occurrences in the Paraná Basin, G. occidentalis has been recognized in the Paganzo and San Rafael basins (Archangelsky et al., 1996). Beyond South America, Bernardes-de-Oliveira \& Pons (1975) doubtfully recorded (as Glossopteris cf. G. occidentalis) this species in the Zambasi Basin, in the Tetê region of Mozambique, southeastern Africa.

Stratigraphically, G. occidentalis was originally interpreted to be restricted to the Rio Bonito Formation but its lower range is now extended to the top of the Itarare Group, based on its occurrences at the Morro do Papaléo outcrop. Thus, it is no longer exclusive to the Glossopteris/Rhodeopteridium Zone of Guerra-Sommer \& Cazzulo-Klepzig (1993) but initiates in the underlying Phyllotheca indica Subzone of the Botrychiopsis plantiana Zone, as outlined by Iannuzzi et al. (2007). Therefore, it ranges from the middle Sakmarian to early Artinskian in the Paraná Basin.

This agrees with its distribution in Argentina, where the species is considered one of the index-fossils for the Early Permian, occurring in the Lower Subzone of the Gangamopteris Zone, according to Archangelsky et al. (1996). In Argentina, this species has been recognized in the Arroyo Totoral and La Colina formations in the Paganzo Basin and in the lower member of the El Imperial Formation of the San Rafael Basin, all considered to be of Asselian-Artinskian age, according to Archangelsky et al. (1996). If confirmed in Mozambique, G. occidentalis occurs in the "Produtive Series" of the Zambezi Basin, tentatively assigned to the Artinskian by Bernardes-de-Oliveira \& Pons (1975). Thus, G. occidentalis characterizes Lower Permian assemblages from intracratonic basins of southwestern Gondwana (southern Brazil, northwest Argentina and possibly Mozambique).

\section{ACKNOWLEDGMENTS}

This research is part of the Ph.D. dissertation of the senior author. The authors wish to thank the National Council for Scientific and Technological Development (Conselho Nacional de Desenvolvimento Científico e Tecnológico - CNPq) for support through grants and aid (processes 130053/20058 and PQ309322/2007-3), fundamental to this research; to William A. DiMichele for the access to the type material deposited at the NMNH of the Smithsonian Institution; to Dan Chaney for the preparation of the photographs of the type material; and to Luiz Flávio Lopes for the production of the photographs of the described material. The authors are also grateful to Pedro Raúl Guttiérrez and Stephen McLoughlin by the review of the manuscript, helping to improve its final version. This research is a contribution of the Gondwana Investigation Center (Centro de Investigação do Gondwana - CIGO) to the CNPq (processes 474153/2004-5, 483463/2007-8) and FAPERGS (PROAPP-04/1066.0) projects. This paper was a contribution to the XII SBPP (Florianópolis, November 02-05th, 2008).

\section{REFERENCES}

Arber, E.A.N. 1905. Catalogue of the Fossil Plants of the Glossopteris Flora. London, British Museum, 295 p.

Archangelsky, S. 1958. Estúdio geológico y paleontológico del Bajo de la Leona (Santa Cruz). Acta Geológica Lilloana, 2:5-133.

Archangelsky, S.; González, C.R.; Cúneo, N.R.; Sabattini, N.; Césari, S.N.; Aceñolaza, F.G.; Garcia, G.B.; Buatois, L.A.; Ottone, E.; Mazzoni, A.F.; Hünicken, M.A. \& Gutiérrez, P.R. 1996. El Sistema Permico en la Republica Argentina y en la Republica Oriental del Uruguay. Córdoba, Academia Nacional de Ciencias, 417 p.

Ash, A.; Ellis, B.; Hickey, L.J.; Johnson, K.; Wilf, P. \& Wing, S. 1999. Manual of leaf architecture: morphological description and categorization of dicotyledonous and net-veined monocotyledonous angiosperms. Washington, Leaf Architecture Working Group of Smithsonian Institution, 65 p. http://www.peabody.yale.edu/collections/pb/MLA.pdf 
Bernardes-de-Oliveira, M.E.C. 1969. Flora da Formação Rio Bonito: Glossopteris, Noeggerathiopsis, Sphenopteris, Gangamopteris e Rhabdotaenia, na subida do Bainha, Criciúma, Santa Catarina. Faculdade de Filosofia, Ciências e Letras, Universidade de São Paulo, Dissertação de Mestrado, 51 p.

Bernardes-de-Oliveira, M.E.C., 1977. Tafoflora Eogondvânica da camada Irapuá, Formação Rio Bonito (Grupo Tubarão), SC. Instituto de Geociências, Universidade de São Paulo, Tese de Doutoramento, $301 \mathrm{p}$.

Bernardes-de-Oliveira M.E.C \& Pons, D. 1975. Taphoflora of Karroo in the Zambezi Basin (Tete Region, Mozambique). Boletim do Instituto de Geociências, 6:33-53.

Bortoluzzi, C.A.; Piccoli, A.E.M.; Bossi, G.E.; Guerra-Sommer, M.; Toigo, M.M.; Pons, M.E.H.; Wolf, M. \& Silva, Z.C.C. 1978. Pesquisa geológica na bacia carbonífera de Santa Catarina. Pesquisas, 11:33-192.

Brongniart, A. 1828. Histoire dês végétaux fossiles ou recherches botaniques et géologiques sur lês végétaux renfermés dans lês diverses couches du globe. Paris, G. Dufour \& Ed. D’Ocagne, 223 p.

Chandra, S. \& Surange, K.R. 1979. Revision of the Indian species of Glossopteris. Lucknow, Birbal Sahni Institute of Palaeobotany, 301 p. (Monografia 2).

Chandra, S. \& Singh, K.J. 1992. The genus Glossopteris from the Late Permian beds of Handapa, Orissa, India. Review of Palaeobotany and Palynology, 75:183-218.

Dilcher, D.L. 1974. Approaches to the identification of angiosperm leaf remains. Botanical Review, 40:1-57.

Dolianiti, E. 1948. A Paleobotânica no Brasil. Rio de Janeiro, Departamento Nacional da Produção Mineral, Divisão de Geologia e Mineralogia, 87 p. (Boletim 123).

Dolianiti, E. 1954a. Gangamopteris angustifolia $e$ Gangamopteris buriadica na Formação Maricá do Rio Grande do Sul. Rio de Janeiro, Departamento Nacional da Produção Mineral, Divisão de Geologia e Mineração, p. 1-6 (Notas Preliminares e Estudos 87).

Dolianiti, E. 1954b. A flora do Gondwana Inferior em Santa Catarina $V$ - gênero Gangamopteris. Rio de Janeiro, Departamento Nacional da Produção Mineral, Divisão de Geologia e Mineralogia, p. 1-12 (Notas Preliminares e Estudos 89).

Feistmantel, O. 1876. Note on the age of some fossil floras of India. Memoirs of the Geological Survey of India, Palaeontologia Indica, 9:28-42.

Feistmantel, O. 1881. The fossil flora of the Gondwana System - 1. The flora of the Talchir-Karharbari Beds. Memoirs of the Geological Survey of India, Palaeontologia Indica, Series 12, 3:49-64.

Guerra-Sommer, M. \& Cazzulo-Klepzig, M. 1993. Biostratigraphy of the Southern Brazilian Neopalaeozoic Gondwana Sequence: a preliminary palaeobotanical approach: In: INTERNATIONAL CONGRÈS DE LA STRATIGRAPHIE ET GÉOLOGIE DU CARBONIFÈRE ET PERMIEN, 12, 1991. Comptes rendus, Buenos Aires, 2:61-72.

Iannuzzi, R.; Marques-Toigo, M.; Scherer, C.M.S.; Caravaca, G; Vieira, C.E.L. \& Pereira, L.S. 2003a. Reavaliação da fitobioestratigrafia da seqüência gondwanica sul-riograndense: estudo de caso do afloramento Morro do Papaléo (bacia do Paraná, Permiano Inferior). In: ENCONTRO SOBRE A ESTRATIGRAFIA DO RIO GRANDE DO SUL: ESCUDO E BACIAS, I, 2003. Anais, Porto Alegre, UFRGS, p. 182-185.

Iannuzzi, R.; Marques-Toigo, M.; Scherer, C.M.S.; Caravaca, G; Vieira, C.E.L. \& Pereira, L.S. 2003b. Phytobiostratigraphical revaluation of the southern Brazilian Gondwana sequence (Paraná Basin, Lower Permian). In: INTERNATIONAL CONGRESS ON CARBONIFEROUS AND PERMIAN STRATIGRAPHY, 15, 2003. Abstracts, Utrecht, p. 240-242.

Iannuzzi, R.; Scherer, C.M.S.; Souza, P.A.; Holz, M.; Caravaca,G.; Adami-Rodrigues, K; Tybusch, G.P.; Souza, J.M.; Smaniotto, L.P.; Fischer, T.V.; Silveira, A.S.; Lykawka, R.; Boardman, D.R. \& Barboza, E.G. 2006. Afloramento Morro do Papaléo, Mariana
Pimentel, RS. Registro ímpar da sucessão pós-glacial do Paleozóico da Bacia do Paraná. In: C. Schobbenhaus; D.A. Campos; E.T. Queiroz; M. Winge \& M.L. Berber-Born (eds.) Sítios Geológicos e Paleontológicos do Brasil. vol. 2. <http:// www.unb.br/ig/sigep/sitio101/sitio101.pdf>

Iannuzzi, R.; Souza, P.A.; Scherer, C.M.S. \& Holz, M. 2007. Plantas fósseis na bioestragirafia dos depósitos permianos do Rio Grande do Sul. In: R. Iannuzzi \& J.C. Frantz (eds.) 50 Anos de Geologia. Instituto de Geociências. Editora Comunicação e Identidade, p. 265-281.

Kovács-Endrödy, E. 1976. Notes on some Glossopteris species from Hammanskraal (Transvaal). Palaeontologia Africana, 19:67-95.

Krebs, A.S.J. 2004. Contribuição ao conhecimento dos recursos hídricos subterrâneos da porção correspondente à bacia do rio Araranguá, SC. Programa de Pós-Graduação em Geografia, Universidade Federal de Santa Catarina, Tese de Doutoramento, 2 v., 376 p.

Kurtz, F. 1921. Atlas de plantas fósiles de la República Argentina. Actas de la Academia Nacional de Ciencias, 7:129-153.

Maheshwari, H.K. 1965. Studies in the Glossopteris Flora of Índia - 22. On some species of the genus Glossopteris from the Raniganj Stage of the Raniganj Coalfield, Bengal. The Paleobotanist, 13:129-143.

McLoughlin, S. 1993. Late Permian plant megafossils from the Bowen Basin, Queensland, Australia: Part 3. Palaeontographica, 231B:31-62.

Mendes, J.C. 1952. The Gondwana formations of southern Brazil: some of their stratigraphical problems, with emphasis on the fossil flora. The Palaeobotanist, 1:335-345.

Pant, D.D. \& Gupta, K.L. 1968. Cuticular structure of some Indian Lower Gondwana species of Glossopteris. Palaeontographica, 124B: $45-81$.

Read, C.B. 1941. Plantas fósseis do Neopaleozóico do Paraná e Santa Catarina. Rio de Janeiro, Departamento Nacional da Produção Mineral, Divisão de Geologia e Mineralogia, 102 p. (Monografia 12).

Rigby, J.F. 1966. The Lower Gondwana floras of the Perth and Collie basins, western Australia. Palaeontographica, 118B:113-152.

Rigby, J.F. 1972. The Upper Palaeozoic flora at Lauro Müller, Santa Catarina, southern Brazil. Anais da Academia Brasileira de Ciências, 44(suplem.):279-293.

Rigby, J.F.; Chandra, S. \& Surange, K.R. 1988. Glossopterid plant remains in the Permian of Western Australia. Memoirs of the Association of Australasian Palaeontologists, 5:73-78.

Rohn, R.; Babinski, M.E.C.B. \& Rösler, O. 1984. Glossopteris da Formação Rio do Rasto no sul do estado do Paraná. In: CONGRESSO BRASILEIRO DE GEOLOGIA, 33, 1984. Anais, Rio de Janeiro, p. 1047-1061.

Schimper, W. 1869-1870. Traité de Paleontologie Vegetale. Tomo 1, Paris, J.B. Boilliers et fils, 738 p.

Srivastava, A.K. 1991. Evolutionary tendency in the venation pattern of Glossopteridales. Geobios, 4:383-386.

Stewart, W.N. \& Rothwell, G.W. 1993. Paleobotany and the evolution of plants. Cambridge, Cambridge University Press, $521 \mathrm{p}$.

Tybusch, G.P. \& Iannuzzi, R. 2008. Reavaliação taxonômica dos gêneros Gangamopteris e Rubidgea, Permiano Inferior da bacia do Paraná, Brasil. Revista Brasileira de Paleontologia, 11:73-86.

Webb, L.J. 1959. A physiognomic classification of Australian rainforests. Journal of Ecology, 47:551-570.

White, D. 1908. Fossil Flora of the Coal Measures of Brazil. In: White I.C., Comissão de Estudos das Minas de Carvão de Pedra do Brasil, Relatório Final. Imprensa Nacional, 2 v., p. 558-568.

White, I.C. 1908. Comissão de Estudos das Minas de Carvão de Pedra do Brasil, Relatório Final. Rio de Janeiro, Imprensa Nacional, 2 v., 617 p.

Received in November, 2008; accepted in January, 2010. 